\title{
Positive Bouguer anomalies in some orogenic belts
}

Sir - In 1968 I drew attention (1970) to the large positive Bouguer anomalies within the orogenic belts of the Western Alps (the Ivrea anomaly), the Norwegian Caledonides (the Lofoten-Vesteralen and Soroya anomalies) and the Appalachian Mountains (e.g., the Sutton-Green Mountain gravitational high). I now reconsider the gravity anomalies in the context of later work.

In discussing the Söröya anomaly of northern Norway, I indicated (1970) that it could be explained either by a tectonic wedge of basic and ultrabasic rocks extending downwards from the surface or by a zone of intrusions extending upwards into the upper crust. I preferred the intrusion hypothesis and developed an argument of Closs (1965) that the upward migration of basic and ultrabasic magma may to an extent control or 'drive' orogenic proœsses at a higher crustal level. Similar conclusions were reached by Innes \& Argun-Weston (in Clark 1967) in their analysis of the Sutton-Great Mountain high of the Appalachian Mountains. They stated that the anomaly 'could arise from large-scale penetration of basic material to higher levels during orogeny'.

Neither in Norway nor in the Appalachians has sufficient seismic refraction work been carried out to test critically the proposed crustal models and in particular to determine whether the high-density zones causing the gravity anomalies in fact extend vertically down to the upper mantle. However, detailed seismic refraction surveys in the Western Alps (Giese, in Niggli 1968) indicate that the analogous Ivrea anomaly is due to a dense body which is underlain by a low-density, sialic layer which may be partially molten. Giese suggested that during the Alpine orogeny the whole crust of the Southern Alps and the Po plain block was thrust over the geosynclinal regime along the tectonic plane of the Insubric Line. In this view, it is necessary to explain the present-day steep dip of the Insubric Line towards the orogenic belt in terms of subsequent overturning. The Ivrea Zone is thus regarded as comprising an overthrust lithospheric plate and the Ivrea anomaly as being caused by pre-Alpine lower crustal rocks of this plate rather than by a deep, Alpine intrusion zone. This view is consistent with plate tectonics theory and has been mentioned briefly in a recent paper by Dewey \& Horsfield (1970).

It is worth investigating the possibility that the Lofoten-Vesterälen anomaly is similarly caused by an overthrust block of lower crustal rocks. Lofoten-Vesteralen is composed mainly of gneisses and granulites intruded by granitic, anorthositic, gabbroic and ultrabasic rocks, for many years regarded as of probable Caledonian age. K-Ar dates on biotites from foliated metasedimentary rocks of Langoy (Vesteralen) show a peak at about 400 m.y. (Neumann 1960) and since these rocks were supposed by Heier (1960) to pass transitionally, with increasing metamorphic grade, into the granulitic rocks of western Langöy the latter were interpreted as Caledonian rocks also. However, Heier \& Compston (1969), in a recent $\mathrm{Rb}-\mathrm{Sr}$ study, showed that the gneisses, granulites and granites have a long Pre-Cambrian history and give no indication (in terms of Rb-Sr ratios) of being affected by the Caledonian orogeny. Ages of the associated basic and ultrabasic intrusions have not been systematically studied but clearly these may also be of Pre-Cambrian rather than Caledonian age.

Therefore it may be postulated, in line with plate tectonics theory, that the Lofoten-Vesterảlen region comprises an overthrust lithospheric plate containing PreCambrian continental crustal rocks. During such overthrusting, lower crustal rocks would have been tectonically transported near to the surface where they would generate the large gravity anomaly which characterises the region. In this view, Lofoten-Vesteralen is separated from the main Caledonian fold belt by a major thrust, equivalent to the Insubric Line of the Alps, and no such tectonic boundary has been recognised.

A different problem arises when attempting to explain the Söröya anomaly, $300 \mathrm{~km}$ to the north east, in similar terms. In that region, a thrust surface crops out to the east of the Seiland basic igneous province which would, if developed into a thick wedge, be sufficient to explain the gravity anomaly. However, the rocks of the Seiland province are indisputably of Caledonian age, being intruded into tectonized Eocambrian meta- 
sediments; they are thus an integral part of the orogenic belt and cannot be regarded as representing deep crustal levels in a pre-Caledonian lithospheric plate.

Such a wedge would not be equivalent tectonically to that which may be postulated to occur in Lofoten-Vesteralen. Thus there are major difficulties in attempting to explain the Bouguer anomalies of the Norwegian Caledonides in terms of the Alpine model proposed by Giese, and these could only be fully resolved by detailed refraction experiments.

\section{REFERENCES}

Brooks, M. 1970. A gravity survey of coastal areas of West Finnmark, northern Norway. Q. Jl geol. Soc. Lond. 125, 171-92.

Clark, T. H. (Ed.) 1967. Appalachian Tectonics. University of Toronto.

Closs, H. 1965. Explosion seismic studies in the Alps and in the German Federal Republic. The Upper Mantle Project Symposium, New Delhi, 1964, 94-102.

Dewey, J. F. \& Horsfield, B. 1970. Plate tectonics, orogeny and continental growth. Nature, Lond., 225, 521-5.

Heier, K. S. 1960. Petrology and geochemistry of high-grade metamorphic and igneous rocks on Langöy, northern Norway. Norg. geol.. Unders. 207, 246 p.

Heier, K. S. \& Compston, W. 1969. Interpretation of Rb-Sr age patterns in high-grade metamorphic rocks, north Norway. Norsk geol. Tidsskr. 49, 257-83.

Neumann, H. 1960. Apparent ages of Norwegian minerals and rocks. Norsk geol. Tidsskr. 40, 173-91.

Niggli, E. (Ed.) 1968. Symposium "Zone Ivrea-Verbano". Schweiz. miner. petrogr. Mitt. 48 (1). 356 p.

Geology Department

M. Brooks

University College

Swansea

Wales, U.K.

22nd May 1970 